\title{
The Effect of US Monetary Policy Normalization Toward The Financing Growth of Indonesian Islamic Banking Industry: Short-Term and Long-Term Approaches ${ }^{1}$
}

\author{
Ahmad Mikail ${ }^{1 *}$ and Kenny Devita Indraswari ${ }^{2}$ \\ ${ }^{1,2}$ University of Indonesia, Depok, Indonesia
}

\begin{abstract}
The study identifies the effect of The Fed Fund Rate (FFR) normalization toward the financing growth of Islamic banks as well as toward the industrial credit growth in Indonesia. To acquire better understanding about the effect of the increasing FFR, Vector Error Correction Model is being utilized in order to identify short run and long run effects. The data employed are the quarterly data of total credit in banking industry, total financing in Islamic banking industry, FFR, real GDP growth, real interest rate, exchange rate and Indonesian composite index from 2003 - 2015. To forecast the dynamic effect of the rising FFR towards financing growth in the Islamic banks, Impulse Response Function is being applied. The result from the long run estimation suggests that the Fed's monetary policy has negative effect toward the Indonesian banking credit growth as well as the Islamic financing growth. Moreover, the estimated coefficient shows that the effect is quite low in the long run for the conventional bank and relatively high for the Islamic banks. From the short run dynamic analysis, the study reveals that the Islamic banks financing growth is mostly determined by FFR where Islamic financing growth affects Indonesian composite index and real interest rate. However, the Impulse Response Function result exhibits that the Fed's monetary policy normalization will not affect Islamic banks financing in Indonesia.
\end{abstract}

Keywords: Fed Fund Rate, Financing Growth, Islamic Banking, Indonesia, Monetary Policy

\section{INTRODUCTION}

The issue of US monetary policy normalization by The Federal Reserve in the end of 2015 has created turbulence in global financial market. This condition also affects Indonesian macroeconomic in the whole year of 2015. The uncertainty about The Fed policy directly or indirectly affected Indonesian economy by several channels. Firstly, the capital outflow from portfolio investment is inevitable if The Fed finally increases The Fed Fund Rate (FFR) in the end of 2015 or in first quarter of 2016. We have been witnessing that the capital outflow has surpassed the performance of Rupiah in 2015 due to tapering off quantitative easing by The Fed in the end of October 2014. Rupiah was depreciated $13.7 \%$ against US Dollar until December 2015 (ytd). The amount of capital that already

* Corresponding author. Email address: ahmadmikailzaini@gmail.com

${ }^{1}$ This paper is a revised version of the paper presented by the authors at the 1st Gadjah Mada International Conference on Islamic Economics and Development, UGM Campus,

Yogyakarta, 2016. 
moved out of Indonesian economy is accounted about 130 trillion Rupiah as of September 2015. Secondly, the increasing of FFR shall reduce the margin spread between doing investment in Indonesia and other countries. It shall also reduce the interest of foreign investor to invest in Indonesian real sector. These will lead to lower Foreign Direct Investment (FDI) in Indonesia. The turmoil of financial sector is directly affected upon Indonesian exchange rate due to floating exchange rate regime.

Moreover, Indonesia was suffering with current account and government account deficit until November 2015. Until September 2015, the current account deficit has reached $1.86 \%$ of GDP. This deficit should be plugged by either portfolio investment or FDI. However, those variables are continuously declining since the third quarter of 2014 until the third quarter of 2015. Figure 1 exhibits the trend of FDI and portfolio investment toward Rupiah depreciation.

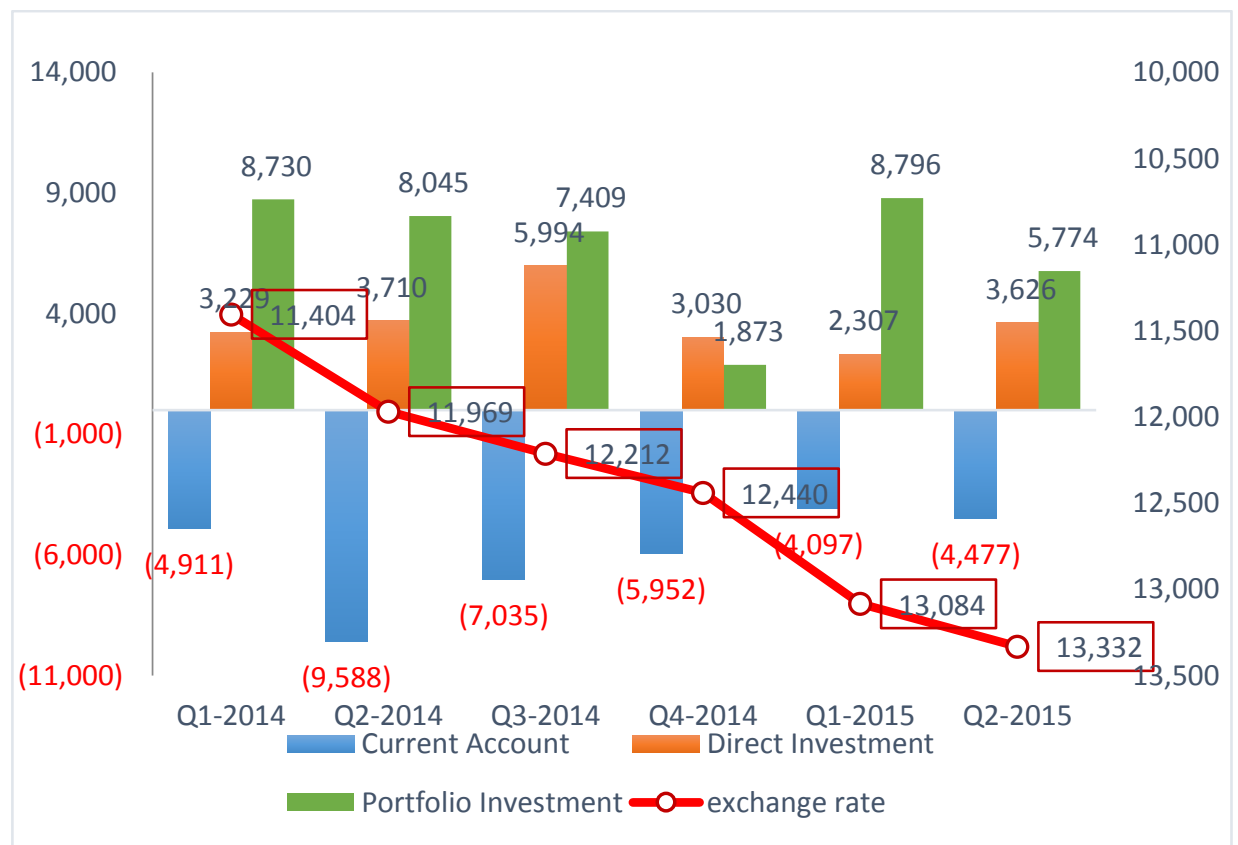

Figure 1 Indonesian Exchange Rate, FDI, Portfolio Investment and Current

Account

Source: Bank Indonesia, 2015

From Figure 1, it can be identified that the declining on portfolio and foreign direct investment were followed by the Rupiah depreciation in 2015. This trend indicates that Indonesian economy depends heavily on the capital account to keep the value of Rupiah. To overcome this problem, Bank Indonesia keeps the interest rate at high level to avoid further capital outflow. As consequences, Indonesian economic growth started to fall from $4.92 \%$ in third quarter of 2014 to $4.73 \%$ in the third quarter of 2015 (yoy). Moreover, the declining of Indonesian economic 
growth is also being followed by the declining on credit growth in the banking industry as well as Islamic banks financing (see Figure 2).
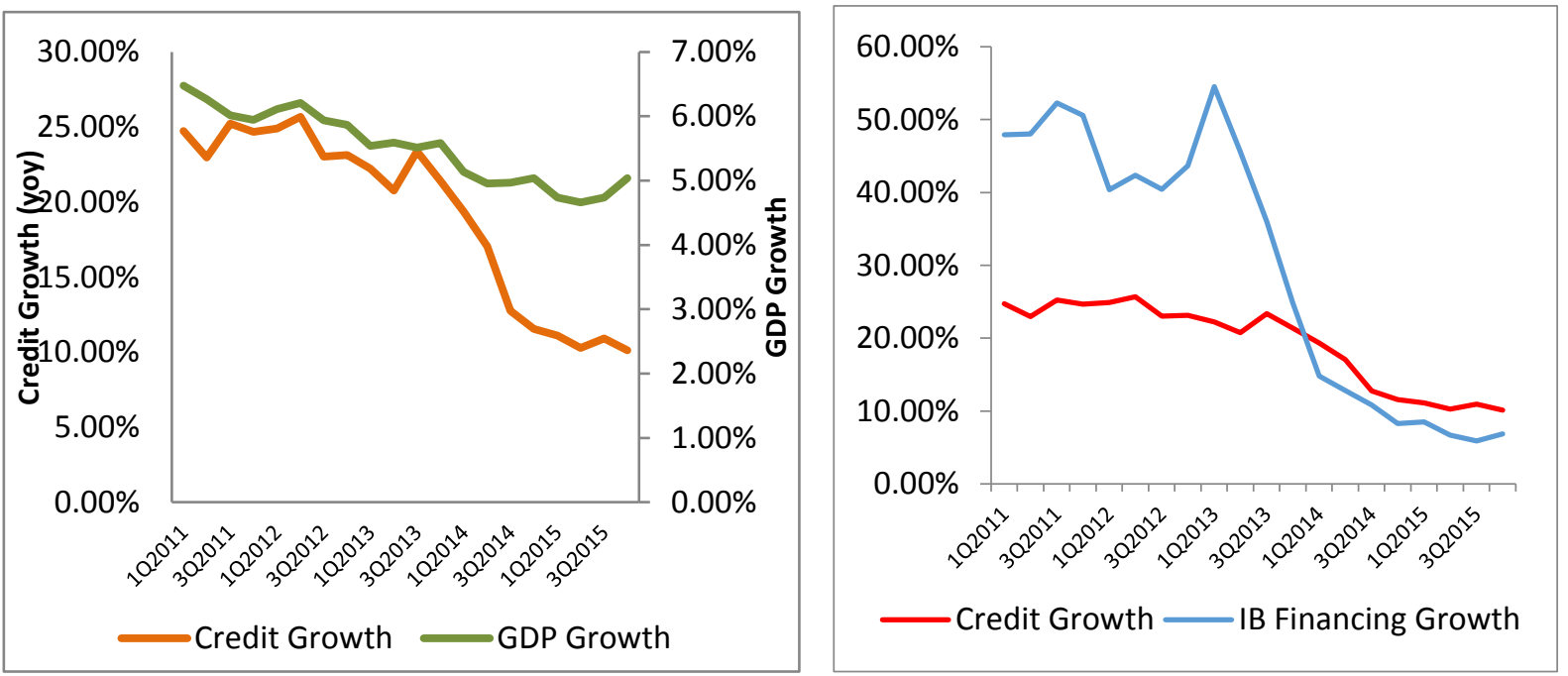

Figure 2 GDP Growth, Credit Growth and Islamic Banks Financing Growth, 2011 - 2015

Source: Bank Indonesia and OJK, 2015

The previous discussion indicates that Indonesian economy is highly sensitive to the global financial market volatility. Any changes on The Fed monetary policy will be channelized toward Indonesian macroeconomic variables that finally lead to the shock on credit growth in the banking industry. As regards to Islamic banking industry, general assumptions say that the responses of the Islamic banks to macroeconomic variables fluctuations are supposed to be different from the conventional banks due to the interest-free instuments (Khan, 1985 in Kassim et al, 2009).

Based on this initial finding, the objective of this study is to analyze the short run and long run effect of any change on the Federal Fund Rate toward Islamic banks financing growth in Indonesia. To achieve this objective, this study compares the impact of the change on FFR on the credit growth in Islamic banks vis-a-vis in the banking industry level in Indonesia. While most of the existing literatures put more focus on the effect of domestic monetary shocks on the Islamic banks deposit and financing, this study adds foreign monetary policy variable into the model. Therefore, it would give a preliminary findings on how sensitive is Islamic banking industry to the global financial market volatility. In efforts to arrive at conclusion, this study utilizes investigation techniques by using Vector Error Correction Model (VECM) and Impulse Response Function (IRF) based on Vector Autoregressive (VAR) methodology. 


\section{LITERATURE STUDY}

The Federal Reserve policy for withdrawing monetary stimulus and increasing interest rates may have a reversal effect for capital flows to the emerging markets. Small and open economy like Indonesia is highly depending on global capital market due to the existence of interest rate disparities between domestic interest rate and foreign interest rate. This interest spread attracts small and open economy to access cheaper capital from international market. Study by Dornbusch (1985 in Giovani and Shambaugh, 2006) concludes that large countries business cycle influences the developing economies through commodity prices, debts and export of manufacture goods. Morover, Calvo, Leiderman and Reinhart (1993 Giovani and Shambaugh, 2006) find that low interest rate in large countries tend to send investor looking other countries which generate high yield investment. The spread between large open economy and small open economy generates capital inflows for developing countries. The proces s can be reserved when the interest rates in large countries increase.

$$
R_{t}=R_{t}^{b}+\frac{E_{t+1}-e_{t}}{e_{t}}
$$

Equation (1) explains the inter-relation between foreign interest rate and domestic interest rate whereby foreign interest rate serves as a rate basis. Floating country allows the domestic exchange rate $\left(e_{t}\right)$ to depreciate and create smaller expected future depreciation and no change in $R_{t}$. In doing so, the cost of local borrowing has not changed and floating rates have served their isolating purpose (Giovani and Shambaugh, 2006). Many previous studies use country's GDP as indicator to assess the effect of foreign monetary policy towards domestic economy. For example, Kim (2001) explores the effect of US domestic interest rate toward business cycle of the remaining G-7 countries. He identifies that US interest rate significantly determines the economic growth of G-7 economy.

With regards to the effect of US monetary policy normalization on capital flows in emerging market economies, the study of Dahlhaus and Vasishtha (2014) record that the impact policy normalization shock on portfolio flows to emerging market economies is economically small. However, this study does not count the interaction between the Fed's monetary policy and country macroeconomic variables. In terms of effect of change in the Federal Fund Rate on credit growth in Philippines, Tan (2012) reveals the coefficient for the FFR is statistically significant with the expected negative sign. This study finds that the most statistically significant variables that affect credit growth is the FFR. Hence, it implies that variable which is beyond the policymakers' control plays an important role in the credit growth in Philippines. The result of this study confirms previous study conducted by Guo and Stepanyan (2011) which finds similar result on negative relationship between the changes in FFR toward credit expansion in emerging market economies.

For the case of Islamic financing, the existing literatures on the effect of foreign monetary policy towards the financing growth in Islamic banking industry is still limited. Given the limitation of the existing literatures under the same topics, for the basis of variables selection, this study selects several studies which discuss about the impact of monetary policy shocks on the Islamic banks. For the case of Islamic banking, it is commonly expected that the response of Islamic banks to the monetary shocks will be different from the conventional banks since the Islamic 
banks are based on interest-free instruments. However, study by Kassim, Majid and Yusof (2009) display the contrary result from the existence of dual banking system in Malaysia. The study finds that the impact of monetary policy is more destabilizing for the Islamic banks rather than for its counterpart, the conventional banks. The same findings appear for the case of other countries with dual banking system such as Turkey (Ergec and Arslan, 2011) and Pakistan (Zaheer, Ongena and Wijnbergen, 2013; Naveed, 2015).

\section{RESEARCH METHODOLOGY}

To analyze the effect of foreign interest rate upon domestic economic variables, several studies apply Vector Autoregressive (VAR) method in order to identify the inter-relation between each variable (Kim, 2001 and Canova, 2005). Based on those previous studies, this study applies VAR to analyze the short-run and long-run effect of FFR toward Indonesian domestic economy especially for the credit growth in banking industry. Moreover, this study also applies Vector Error Correction Model (VECM) if Granger Causality test shows the existing long run relationship between each variable at level.

Engle and Granger (1987, in Bekhet and Yusop ,2009) show that in the presence of co-integration, there is always be an existence of a corresponding errorcorrection representation. This implies that changes in the dependent variable are a function of the level of disequilibrium in the co-integrating relationship which is captured by the error-correction term and changes in other explanatory variables. Vector Autoregressive (VAR) is the common ways to analyze several economic variables which are interrelated to each other. Hence, the framework of VAR is suitable to achieve the aims of this study since it alows all variables to be potentially endogenous while minimizing the theoretical restrictions (Ibrahim and Shah, 2012).

If we exploit that there may exist co-movements among a set of time series and possibilities that they will trend together in finding a long run stable equilibrium, by Granger representation theorem, we may posit the following testing relationships which constitute the VECM (Mukhtar and Rasheed, 2010). Consider a set of variables that are $\mathrm{I}(0)$ after applying the differencing filter once. Provided that the variables in Xt are also co-integrated of order $r$, we may impose this constraint upon our unrestricted VAR to enable a VECM formulation as:

$$
\Delta X_{t}=\sum_{i=1}^{n} \Delta X_{t-1}+\sum_{i=1}^{r} \delta_{i} \theta_{t-1}+v_{t}
$$

This study replicates the VECM framework above to build the model. This study focuses on the credit and financing growth model as an indicator of banking industry performance. Previous studies suggest that GDP, FDI, inflation, interest rate set by the central bank, exchange rate are the variables which determine the credit growth as well as financing growth. Accordingly, this study estimates a six-variable VAR using credit growth in banking industry (CreditG), financing growth in Islamic banking industry $(L I B F)$, real GDP growth $(R G D P)$, real interest rate $($ Rint $)$, Fed Fund Rate $(F F R)$, Indonesian Composite Index (LIHSG), exchange rate (Lexch) as the variables in the system. Therefore, this study focuses on the following basic functions: 


$$
\begin{aligned}
& X_{1}=\{R G D P, \text { Rint }, \text { FFR, LIHSG, Lexch, CreditG }\} \\
& X_{2}=\{R G D P, \text { Rint }, \text { FFR, LIHSG, Lexch, LIBF }\}
\end{aligned}
$$

The credit $($ Credit $G)$ and financing $(L I B F)$ variables are based on year on year basis. These variables are expected to be influenced by all other variables in the VAR system. Real GDP growth $(R G D P)$ is GDP growth deducted by inflation rate. The relationship between real GDP growth and credit growth as well as financing growth is estimated to be positive. Moreover, real interest rate (Rint) is calculated from the BI rate deducted by inflation rate. Rint and FFR are expected to have negative relationship with credit growth and financing growth. LIHSG is captured by the Indonesian composite index in the natural $\log$ form. According to the Tobin's Q theory, $L I H S G$ is estimated to have positive relationship with credit growth and financing growth. Meanwhile, for exchange rate in the log natural form (Lexch), the relationship is expected to be positive. The data are gathered from various publications of the Central Bank of Indonesia, the National Statistical Bureau of Indonesia and the Financial Service Authority of Indonesia. Using quarterly data, this study covers the period from 2003 to 2015.

\section{RESULTS AND DISCUSSION}

\subsection{Unit Root Test and Co-Integration Test}

Based on Engle and Granger (1987), the limitation of time series analysis is unit root problem as it may generates a spurious regression. To identify the unit root problem, this study applies the widely used Augmented Dickey Fuller (ADF) and Philip-Perron (PP) tests to detect the existence of autocorrelation between error terms. Each test includes intercept and trend in every diagnostic process. The result shows that for the credit growth and financing growth models, all of the data are non-stationary at level Nevertheless, critical value of those variables cannot reject the null hypothesis in all of ADF test. Furthermore, null hypothesis can be rejected at first difference in ADF and PP test. Therefore, it implies that the data of RGDP, Rint, FFR, LIHSG, Lexch, CreditG, LIBF are stationary at first difference (I).

After knowing that all of data are stationary at first difference, the next step is to determine optimum lag of interest rate pass-through model. Before using Hamman-Quinnon (H-Q) or Schwarz Information Criterion (SC), VAR estimation should be conducted and use its residual to implement the test. As regards to optimum lag, we find there are differences between credit growth model and financing growth model. For credit growth model, we have four maximum lag to avoid non-stationary problem in the data while the maximum lag for financing growth model is three. Table 1 depicts the result of Johansen-Juselius Cointegration test for the credit growth model and financing growth model. The result indicates that there are at least 2 or 4 co-intgeration in the long run for each model. Hence, we may run the long-term model of credit growth and financing growth at level (Ibrahim and Shah, 2012). 
The Effect of US Monetary Policy Normalization Toward The Financing Growth of Indonesian Islamic Banking Industry: Short-Term and Long-Term Approaches

Table 1 Johansen-Juselius Co-integration Test

\begin{tabular}{|c|c|c|c|}
\hline \multicolumn{4}{|c|}{ Credit Growth Model } \\
\hline $\begin{array}{l}\text { Hyp } \\
\text { othe } \\
\text { size } \\
\text { d } \\
\end{array}$ & $\begin{array}{c}\text { Tra } \\
\text { ce }\end{array}$ & $\begin{array}{c}\text { Ma } \\
\text { X- } \\
\text { Eig } \\
\text { en }\end{array}$ & $\begin{array}{c}\text { Critical } \\
\text { Values } \\
(5 \%)\end{array}$ \\
\hline $\begin{array}{l}\text { No. } \\
\text { of } \\
\text { CE }\end{array}$ & $\begin{array}{l}\text { Stat } \\
\text { istic }\end{array}$ & $\begin{array}{l}\text { Stat } \\
\text { istic }\end{array}$ & $\begin{array}{c}\text { Tr } \\
\text { ac } \\
\text { e }\end{array}$ \\
\hline
\end{tabular}

s)

Ei

\begin{tabular}{|c|c|c|c|}
\hline \multicolumn{4}{|c|}{ Financing Growth Model } \\
\hline $\begin{array}{l}\text { Hyp } \\
\text { othe } \\
\text { size } \\
\text { d }\end{array}$ & $\begin{array}{c}\text { Tra } \\
\text { ce }\end{array}$ & $\begin{array}{c}\text { Ma } \\
\text { X- } \\
\text { Eig } \\
\text { en }\end{array}$ & $\begin{array}{c}\text { Critical } \\
\text { Values } \\
(5 \%)\end{array}$ \\
\hline $\begin{array}{c}\text { No. } \\
\text { of } \\
\text { CE }\end{array}$ & $\begin{array}{l}\text { Stat } \\
\text { istic }\end{array}$ & $\begin{array}{l}\text { Stat } \\
\text { istic }\end{array}$ & $\begin{array}{l}\text { Tr } \\
\text { ac } \\
\text { e }\end{array}$ \\
\hline
\end{tabular}

\begin{tabular}{|c|c|c|c|c|}
\hline & & & & $\begin{array}{l}\text { ge } \\
\text { n }\end{array}$ \\
\hline$r=0$ & $\begin{array}{c}275 . \\
6245 \\
* * *\end{array}$ & $\begin{array}{r}90.0 \\
2671 \\
* * *\end{array}$ & $\begin{array}{c}95 . \\
753 \\
66\end{array}$ & $\begin{array}{c}40 . \\
077 \\
57\end{array}$ \\
\hline$r \leq 1$ & $\begin{array}{c}185 . \\
5978 \\
* * *\end{array}$ & $\begin{array}{c}74.1 \\
4253 \\
* * *\end{array}$ & $\begin{array}{c}69 . \\
818 \\
89\end{array}$ & $\begin{array}{c}33 . \\
876 \\
87\end{array}$ \\
\hline$r \leq 2$ & $\begin{array}{c}111 . \\
4552 \\
* * *\end{array}$ & $\begin{array}{c}53.8 \\
3510 \\
* * *\end{array}$ & $\begin{array}{c}47 . \\
856 \\
13\end{array}$ & $\begin{array}{c}27 . \\
584 \\
34\end{array}$ \\
\hline $\mathrm{r} \leq 3$ & $\begin{array}{c}57.6 \\
2013 \\
* * *\end{array}$ & $\begin{array}{c}32.3 \\
9880 \\
* * *\end{array}$ & $\begin{array}{c}29 . \\
797 \\
07\end{array}$ & $\begin{array}{c}21 . \\
131 \\
62\end{array}$ \\
\hline $\mathrm{r} \leq 4$ & $\begin{array}{c}25.2 \\
2133 \\
* * *\end{array}$ & $\begin{array}{c}21.2 \\
7311 \\
* * *\end{array}$ & $\begin{array}{c}15 . \\
494 \\
71\end{array}$ & $\begin{array}{c}14 . \\
264 \\
60\end{array}$ \\
\hline $\begin{array}{l}\text { Note: } \\
\text { signific } \\
\text { signific } \\
* * * \text { sig }\end{array}$ & $\begin{array}{l}\text { at } 5 \\
\text { cant }\end{array}$ & $\begin{array}{l}\text { signif } \\
1 \%\end{array}$ & $\begin{array}{l}\text { at } 10 \\
\text { tes }\end{array}$ & els, \\
\hline
\end{tabular}

s)

Ei

\begin{tabular}{ccccc} 
& & & & ge \\
& & & & $\mathbf{n}$ \\
\hline & 188. & 78.2 & 95. & 40. \\
$\mathrm{r}=0$ & 9143 & 1619 & 753 & 077 \\
& $* * *$ & $* * *$ & 66 & 57 \\
& 110. & 47.9 & 69. & 33. \\
$\mathrm{r} \leq 1$ & 6981 & 9946 & 818 & 876 \\
& $* * *$ & $* * *$ & 89 & 87 \\
& 62.6 & 26.6 & 47. & 27. \\
$\mathrm{r} \leq 2$ & 9866 & 3577 & 856 & 584 \\
& $* * *$ & $*$ & 13 & 34 \\
& 36.0 & 21.2 & 29. & 21. \\
$\mathrm{r} \leq 3$ & 6289 & 1910 & 797 & 131 \\
& $* * *$ & $* *$ & 07 & 62 \\
& 14.8 & 10.3 & 15. & 14. \\
$\mathrm{r} \leq 4$ & 4379 & 0830 & 494 & 264 \\
& $*$ & & 71 & 60 \\
\hline
\end{tabular}

Note: *denotes significant at $10 \%$ significance level, ** denotes significant at $5 \%$ significance levels. *** significant at $1 \%$

\subsection{Long-Run Relationship}

Given the presence long term of co-integration among variables, we can see how these variables are tied in the long run. We normalize the long run relation on the credit growth and financing growth, as depicted below (*indicates significance at $10 \%, * *$ significance at $5 \%, * * *$ significance at $1 \%$ ):

Credit Growth Model

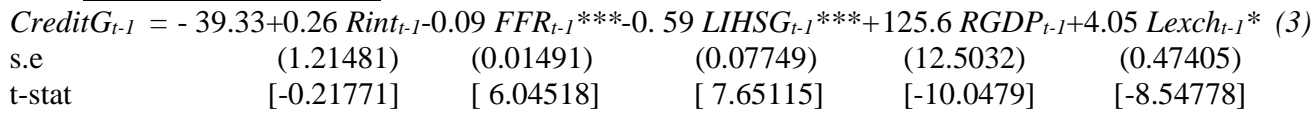

Islamic Banks Financing Growth Model

$\begin{array}{lccccc}\text { LIBF F }_{t-1}=-6.82-15.7 \text { Rint }_{t-1}-0.19 & \text { FFR } & \text { 6.- } & * * *+1.31 & \text { LIHSG }_{t-1} * *-62.70 ~ R G D P_{t-1}-0.25 \text { Lexch }_{t-1} \\ \text { s.e } & (2.95871) & (0.03048) & (0.12035) & (14.8874) & (0.82237) \\ \text { t-stat } & {[5.29972]} & {[6.31125]} & {[-10.8492]} & {[4.21170]} & {[0.29940]}\end{array}$


For the credit growth model, equation (3) exhibits that in the long run, exchange rate, IHSG and FFR play important role in determining banking industry credit growth. Credit growth in banking industry is found to be positively related to exchange rate. This result concurs well with the result of Arsana (2005) which finds that exchange rate depreciation increases the risk of non-performing loan, hence the banks reduce their loans. Meanwhile, for the financing growth in Islamic banking, the estimation result in equation (4) shows that in the long run, financing growth in Islamic banks is negatively related to FFR but positively related to IHSG. With regard to IHSG, it is interesting to note that IHSG has different relation with credit growth and financing growth model. The plausible explanation for this result is the existence of trade-off from the perspective of corporations. Negative sign between IHSG and credit growth indicates trade-off between borrowing money from banks and issuing equity in capital market. At the same time, Islamic banks will get benefit from increasing capital inflow which is marked by the increasing of IHSG. It leads to higher amount of deposit for Islamic banks hence it increases the capacity of Islamic banks to give more financing.

As expected before, credit growth in banking industry is negatively related to Fed Fund Rate variable. From the coefficient, other variables remain constant, if The Fed increases one basis point of its interest rate, credit growth in Indonesia will reduce by 0.09 basis point. This result is in line with the previous studies for Philippine (Tan, 2012) and emerging economy countries (Guo, 2011) cases. The same pattern also prevails for the case of financing growth in Islamic banks. However, the estimated parameters indicate that FFR has stronger negative effect towards credit growth in Islamic banking industry rather than in total banking industry. One basis point increase in Fed Fund Rate will reduce financing growth in Islamic banks by 0.19 basis point. Nevertheless, it should be noted that the equation provides information on how credit growth and financing growth are related to FFR and other variables in the long run but it does not express the causal patterns among variables.

\subsection{Short-Run Relationship}

The short-run relationship is being determined by conducting Granger Causality test. The Granger Causality test portrays how each variable is related simultaneously since it is assumed that all variables are interdependent to each other. The result of Granger Causality test is exhibited in Table 2. The significant relationship between variables could be traced by Chi-sq probability. Nevertheless, based on Masih and Masih (1996), we could not read the coefficient of Granger Causality test but we could only identify which of variables that determine the other. For instance, FFR is significant in determining the Islamic banks financing growth in the short-run with alpha $10 \%$ (see Table 2). 
The Effect of US Monetary Policy Normalization Toward The Financing Growth of Indonesian Islamic Banking Industry: Short-Term and Long-Term Approaches

Table 2 Granger Causality Test Matrix Result for Financing Growth of Islamic Banks Model

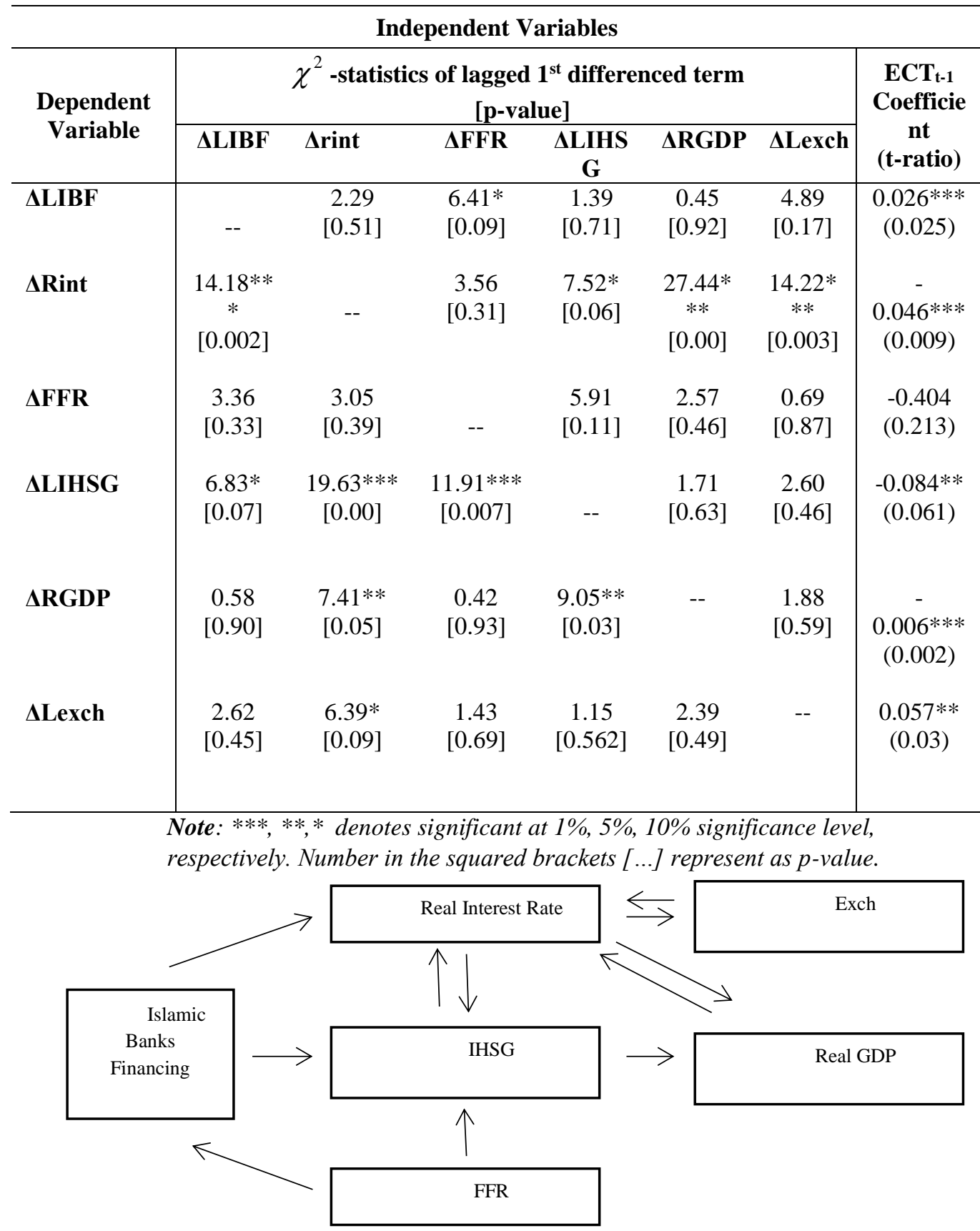

Figure 3 Mapping Matrix Result

Figure 3 depicts that FFR determines IHSG and Islamic banks financing growth. According to the result, it can be inferred that within several months, any changing 
on the Fed monetary policy (FFR) will change Indonesian composite index and Islamic banks financing growth significantly. As compared to the result of Granger Causality test for the credit growth model, it can be seen that the effect of FFR in the total banking industry and Islamic banking industry has the same pattern. In both industries, FFR is significant to determine the credit growth and IHSG in the short run (see Appendix 1).

\subsection{Forecasting Analysis}

Generalized Impulse Response Function (GIRF) is conducted to gauge to what extent the shocks to certain variable are explained by other variable in the system. Based on IRF result in Figure 4, we find that any positive shock of macroeconomic variables in Islamic banking financing model is not positively or negatively responded by Islamic financing growth. The effect of FFR does not affect the growth of Islamic financing until the next ten quarter. It indicates that Islamic financing is not correlated with global interest based transmission mechanism. Hence, it indicates that Islamic financing is not affected by US monetary normalization until the next ten quarter. Islamic financing growth is only affected by previous Islamic financing. The positive shock of previous Islamic financing is positively responded by future Islamic financing until the next five quarter. Based on this result, it is important to improve current Islamic financing growth to accelerate the financing of Islamic bank in the future.

At the same time, GIRF for Islamic banking financing model shows that any one standard deviation positive shock IHSG will be responded positively toward real GDP which is significant for the next four quarter and start to decline in six quarter. This result shows that Indonesian economy is quite responsive with capital inflow due to current account deficit problem. Portfolio investment is really helping to plug the hole of current account deficit which creates volatility toward Indonesian rupiah.

For Islamic Banks Financing Growth Model
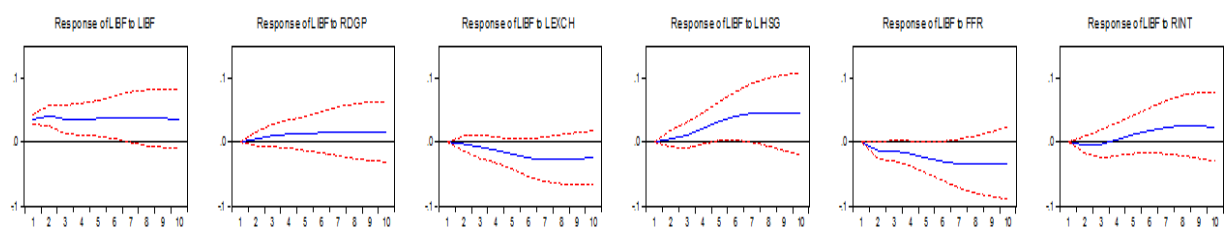

For Credit Growth Model
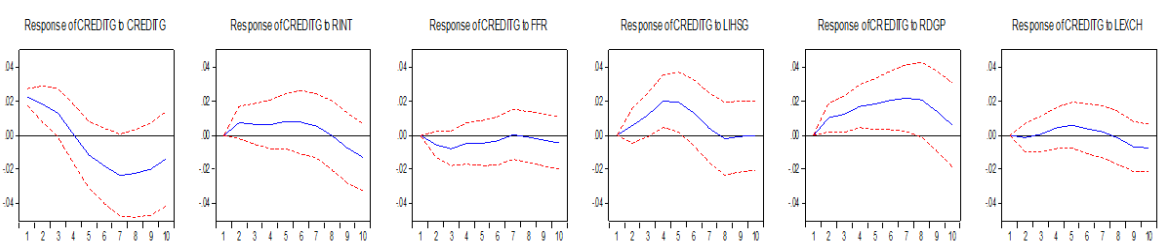

Figure 4 Generalized Impulse Response Function

On the other hand, the IRF result for the credit growth for the banking industry model shows the same result compared to Islamic bank financing model. Each 
positive shock toward macroeconomic variables in the model is not significantly responded by credit growth for the next ten quarter. At the same time, any positive shock toward credit growth will be affected positively on credit growth for the next five quarter. This result shows that better credit growth today will help the performance of credit growth in the future since more credit growth means more liquidity in the market and it will possibly reduce the Non-Performing Loans.

\section{CONCLUSION}

This study utilizes time series techniques of Vector Error Correction Model to evaluate the effect of US monetary policy normalization toward financing growth in Islamic banks for Indonesian case in the short run and long run. The Federal Fund Rate (FFR) is being used as the indicator for the US monetary policy tool. The findings from the co-integration test suggest that there is a common path that ties these variables together in the long run. The estimated long run equation reveals that normalization of The Fed monetary policy has negative effect toward Indonesian banking credit growth and Islamic Financing growth. The coefficient estimation shows that the effect of The Fed normalization is quite low in the long run for conventional bank and relatively high for Islamic banks. This could be traced back in 2015 where the Non-Performing Financing of Islamic banks is relatively high compared to conventional bank. The fluctuation in FFR leads to the volatility of domestic exchange rate currency and increases the NPF of Islamic Banks. From the short run dynamic analysis, this study finds that Islamic banks financing growth is mostly determined by FFR where Islamic financing growth affects IHSG and real interest rate. However, the GIRF result marks that the effect of The Fed normalization will not affect Islamic banks financing for the next ten quarters. It exhibits that the long term relationship between FFR and Islamic financing growth is not quite strong although it is significantly correlated.

However, several caveats limit the conclusion of the study. First, it covers limited number of observation because this study employs quarterly data. As consequence, this study cannot include more than 6 variables in the model. Therefore, by extending the time period of the study, the effect of other macroeconomic variables toward financing growth in Islamic banks can be captured. Second, this study elaborates the effect of US monetary policy normalization on the financing side of Islamic banks only. Future studies may discuss the effect of such policy toward other variables in balance sheet of the banks, such as Non-Performing Financing (NPF). With the inclusion of NPF variable, the effect of Federal Fund Rate changes on Islamic banks stability can be examined.

\section{References}

Arsana, I.G.P. (2005). Pengaruh Nilai Tukar terhadap Aliran Kredit dan Mekanisme Transmisi Kebijakan Moneter Jalur Kredit. Jurnal Ekonomi dan Pembangunan Indonesia, 5(2), $121-140$.

Bekhet, H.A., \& N.Y.M. Yusop. (2009). Assessing the Relationship between Oil Prices, Energy Consumption and Macroeconomic Performance in Malaysia: 
Co-integartion and Vector Error Correction Model (VECM) Approach. International Business Research, 2(3), 153-175.

Calvo, G. A., Leonardo L., \& Carmen M. R. (1993). Capital Inflows and Real Exchange Rate Appreciation in Latin America: The Role of External Factors. Staff Papers (International Monetary Fund), 40(1), 108 - 151.

Canova, F. (2005). The Transmission of US Shocks to Latin America. Journal of Applied Econometrics, 20, 229-251.

Dahlhaus, T., \& Garima V. (2014). The Impact of US Monetary Policy Normalization on Capital Flows to Emerging-Market Economies. Bank of Canada Working Paper, 53.

Dornbusch, R. (1985). Policy and Performance Links between LDC Debtors and Industrial Nations. Brookings Papers on Economic Activity, 2, 303-68.

Engle, R. F., \& C.W.J. Granger. (1987). Co-Integration and Error Correction: Representation, Estimation, and Testing. Econometrica, 55(22), $251-276$.

Ergec, E.H., \& B.G. Arslan. (2011). The Impact of Interest Rate on Islamic and Conventional Banks: The Case of Turkey. MPRA Paper No. 29848.

Giovani, J., \& J. C, Shambaugh. (2006). The Impact of Foreign Interest Rates on the Economy: The Role of the Exchange Rate Regime". IMF Working Paper, $W P / 06 / 37$.

Guo, K., \& V, Stepanyan. (2011). Determinants of Bank Credit in EMEs. IMF Working Paper, $11 / 51$.

Ibrahim, M. H., \& M.E. Shah. (2012). Bank Lending, Macroeconomic Conditions and Financial Uncertainty: Evidence from Malaysia. Review of Development Finance, 2, $156-164$.

Kassim, S.H., M. Shabri Abd. Majid., and Rosylin Mohd Yusof. (2009). Impact of Monetary Policy Shocks on the Conventional and Islamic Banks in a Dual Banking System: Evidence from Malaysia. Journal of Economic Cooperation and Development, 30 (1), 41-58.

Khan, A. (1985). Adjustment Mechanism and Money Demand Function in Pakistan. Pakistan Economic and Social Review, 2, 257- 261.

Kim, S. (2001). International Transmission of US Monetary Policy Shocks: Evidence from VAR's. Journal of Monetary Economics, 48, 339 - 372.

Masih, A.M.M., \& R. Masih. (1996). Empirical Test to Discern the Dynamic Causal Chain in Macroeconomic Activity: New Evidence from Thailand and Malaysia based on a Multivariate Cointegration/Vector Error-Correction Modelling Approach. Journal of Policy Modelling, Vo 18(5), 531-560.

Mukhtar, Tahir., \& S. Rasheed. (2010). Testing Long Run Relationship between Exports and Imports: Evidence from Pakistan. Journal of Economic Cooperation and Development, Vol. 31(1), $41-58$.

Naveed, M. Y. (2015). Impact on Monetary Policy Shocks in a Dual Banking System in Pakistan: A Vector Auto Regressive Approach. European Academic Research, II (11),14684-14700.

Tan, T. B. P. (2012). Determinants of Credit Growth and Interest Rate Margins in the Pihilippines and Asia. IMF Working Paper, 12/123.

Zaheer, S., S. Ongena., \& Sweder J.G. van Wijnbergen. (2013). The Transmission of Monetary Policy through Conventional and Islamic Banks. International Journal of Central Banking, 9(4), 175 - 222. 
The Effect of US Monetary Policy Normalization Toward The Financing Growth of Indonesian Islamic Banking Industry: Short-Term and Long-Term Approaches

APPENDIX 1. Granger Causality Test Matrix Result for Financing Growth of Islamic Banks Model

\begin{tabular}{|c|c|c|c|c|c|c|c|}
\hline \multicolumn{8}{|c|}{ Independent Variables } \\
\hline \multirow[t]{2}{*}{$\begin{array}{c}\text { Dependent } \\
\text { Variable }\end{array}$} & \multicolumn{6}{|c|}{$\chi^{2}$-statistics of lagged $1^{\text {st }}$ differenced term } & \multirow{2}{*}{$\begin{array}{c}\mathbf{E C T}_{\mathbf{t}-1} \\
\text { Coefficient } \\
\text { (t-ratio) }\end{array}$} \\
\hline & $\Delta$ CreditG & $\Delta$ Rint & $\Delta$ FFR & DLIHSG & $\Delta$ RGDP & $\Delta$ Lexch & \\
\hline$\Delta$ CreditG & -- & $\begin{array}{l}7.95^{*} \\
{[0.09]}\end{array}$ & $\begin{array}{l}7.41^{*} \\
{[0.12]}\end{array}$ & $\begin{array}{c}19.89^{* * * *} \\
{[0.00]}\end{array}$ & $\begin{array}{l}9.22 * * \\
{[0.05]}\end{array}$ & $\begin{array}{l}11.1^{* *} \\
{[0.02]}\end{array}$ & $\begin{array}{c}-0.132 * * \\
(0.046)\end{array}$ \\
\hline$\Delta$ rint & $\begin{array}{c}3.69 \\
{[0.45]}\end{array}$ & -- & $\begin{array}{c}0.43 \\
{[0.98]}\end{array}$ & $\begin{array}{c}4.67 \\
{[0.32]}\end{array}$ & $\begin{array}{c}7.05 \\
{[0.13]}\end{array}$ & $\begin{array}{c}1.45 \\
{[0.83]}\end{array}$ & $\begin{array}{l}-0.006 \\
(0.038)\end{array}$ \\
\hline$\Delta F F R$ & $\begin{array}{l}9.13 * * \\
{[0.05]}\end{array}$ & $\begin{array}{c}4.45 \\
{[0.34]}\end{array}$ & -- & $\begin{array}{c}6.14 \\
{[0.18]}\end{array}$ & $\begin{array}{c}14.02 * * * \\
{[0.007]}\end{array}$ & $\begin{array}{c}11.98 * * * \\
{[0.01]}\end{array}$ & $\begin{array}{c}0.061 \\
(0.762)\end{array}$ \\
\hline ALIHSG & $\begin{array}{c}28.62 * * * \\
{[0.00]}\end{array}$ & $\begin{array}{c}31.57 * * * \\
{[0.00]}\end{array}$ & $\begin{array}{c}11.92 * * * \\
{[0.01]}\end{array}$ & -- & $\begin{array}{c}17.7 * * * \\
{[0.00]}\end{array}$ & $\begin{array}{c}5.28 \\
{[0.26]}\end{array}$ & $\begin{array}{l}0.335^{*} \\
(0.181)\end{array}$ \\
\hline$\triangle$ RGDP & $\begin{array}{c}09.55^{* *} \\
{[0.04]}\end{array}$ & $\begin{array}{c}6.45 \\
{[0.17]}\end{array}$ & $\begin{array}{c}4.23 \\
{[0.37]}\end{array}$ & $\begin{array}{c}6.61 \\
{[0.16]}\end{array}$ & -- & $\begin{array}{c}7.16 \\
{[0.12]}\end{array}$ & $\begin{array}{c}0.019^{* * *} \\
(0.007)\end{array}$ \\
\hline$\Delta l e x c h$ & $\begin{array}{l}8.48 * \\
{[0.08]}\end{array}$ & $\begin{array}{l}5.07^{*} \\
{[0.28]}\end{array}$ & $\begin{array}{c}6.35 \\
{[0.17]}\end{array}$ & $\begin{array}{c}1.33 \\
{[0.85]}\end{array}$ & $\begin{array}{c}3.88 \\
{[0.42]}\end{array}$ & -- & $\begin{array}{l}-0.153 \\
(0.124)\end{array}$ \\
\hline
\end{tabular}

Note: $* * *, * * *$ denotes significant at 1\%, 5\%, 10\% significance level, respectively. Number in the squared brackets [...] represent as p-value. 
The Effect of US Monetary Policy Normalization Toward The Financing Growth of Indonesian Islamic Banking Industry: Short-Term and Long-Term Approaches

APPENDIX 2. GIRF for Islamic Banks Financing Model
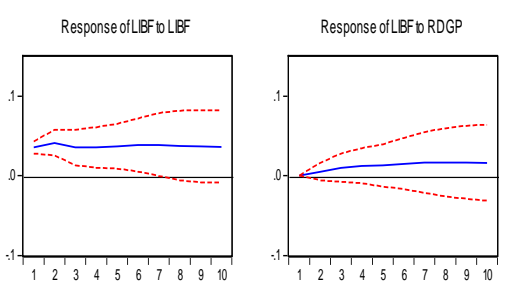

Response to Cholesky One S.D. Innovations \pm 2 S.E.
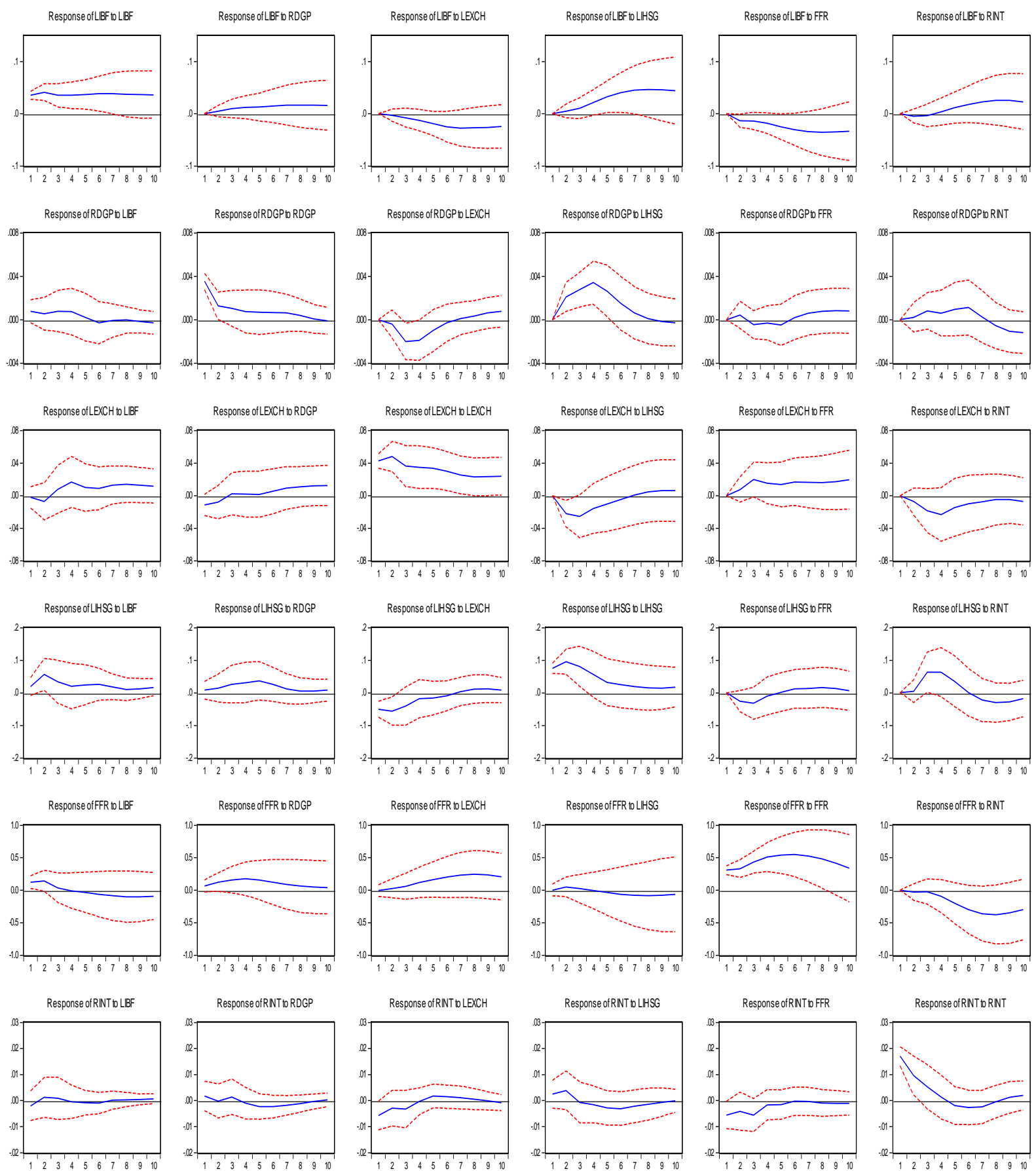
The Effect of US Monetary Policy Normalization Toward The Financing Growth of Indonesian Islamic Banking Industry: Short-Term and Long-Term Approaches

\section{APPENDIX 3. GIRF for Credit Growth Model}
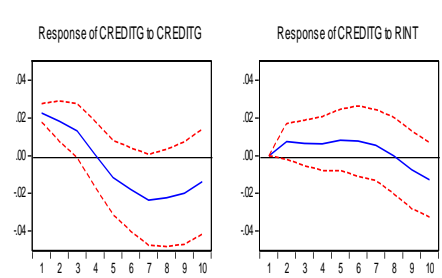

Response to Cholesky One S.D. Innovations \pm 2 S.E.
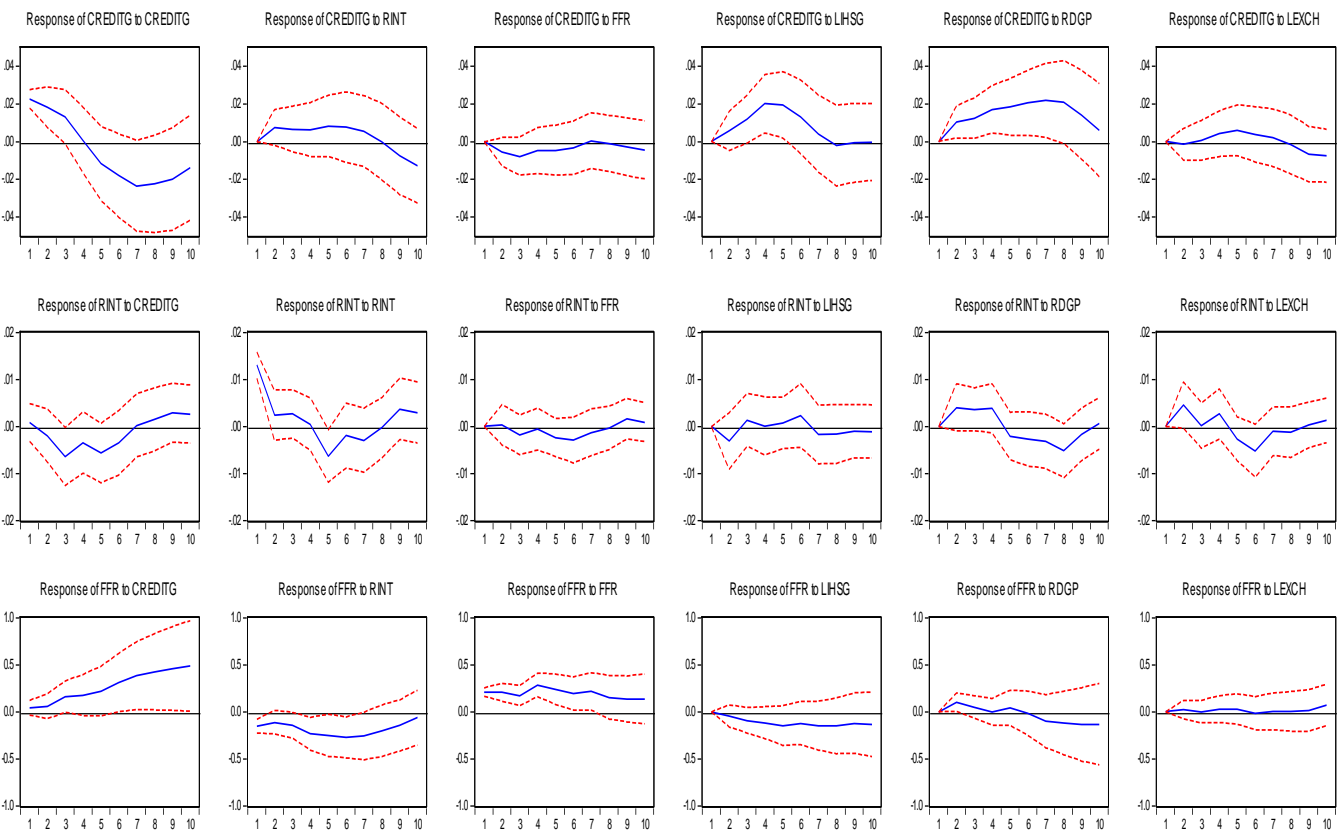

Response ofLLHSG TR CREDTG
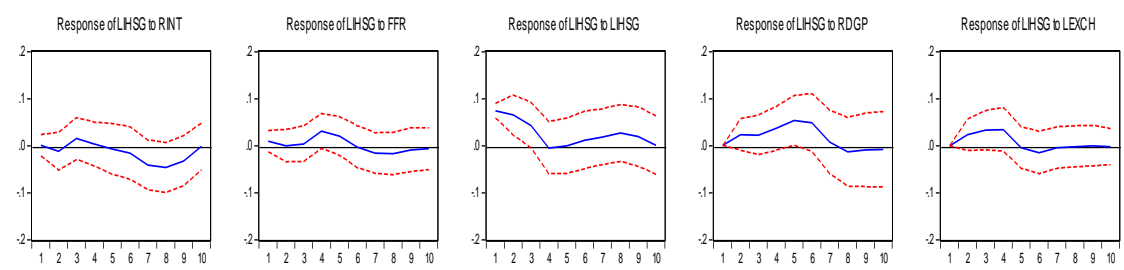

Response OARDGP D CREDTG
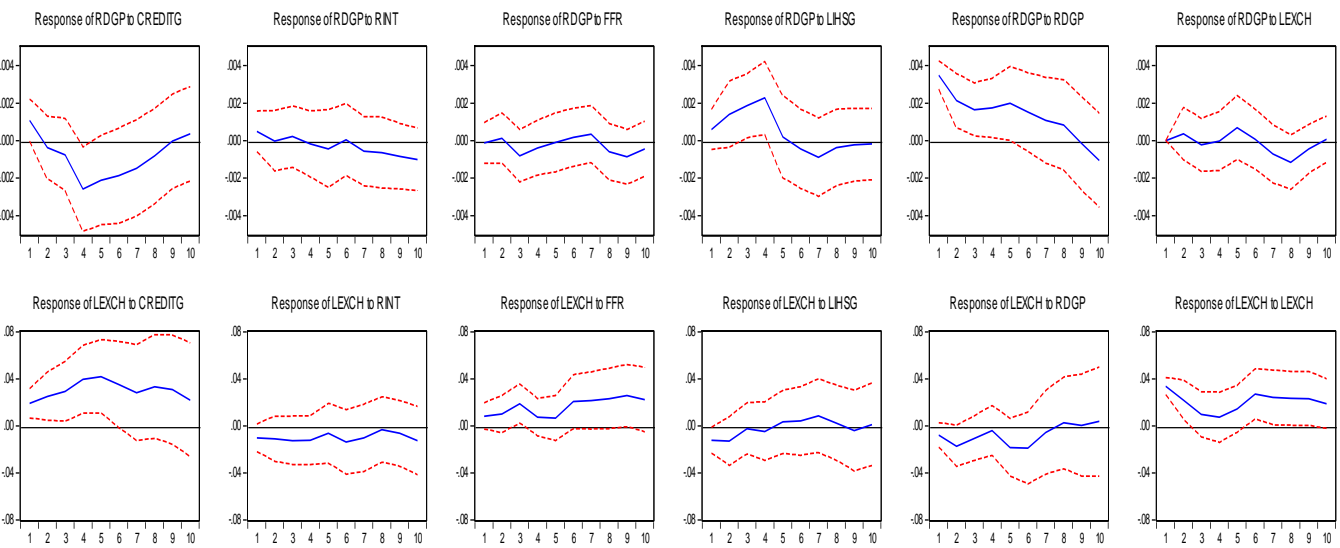